\title{
Methodology for Determining Relationships Between Inoculum Concentration of Botrytis cinerea and Penicillium expansum and Stem End Decay of Pear Fruit
}

\author{
Robert A. Spotts and Kelly M. Wallis, Oregon State University Mid-Columbia Agricultural Research and Extension \\ Center, Hood River 97031; Maryna Serdani, Department of Botany and Plant Pathology, Oregon State University, \\ Corvallis 97331; and Daniel T. O'Gorman and Peter L. Sholberg, Pacific Agri-Food Research Centre, Agriculture \\ and Agri-Food Canada, Summerland, BC V0H 1Z0, Canada
}

\begin{abstract}
Spotts, R. A., Wallis, K. M., Serdani, M., O’Gorman, D. T., and Sholberg, P. L. 2008. Methodology for determining relationships between inoculum concentration of Botrytis cinerea and Penicillium expansum and stem end decay of pear fruit. Plant Dis. 92:451-455.

The objective of this research was to determine quantitative relationships between incidence of stem end decay of pear fruit and inoculum concentration of Botrytis cinerea and Penicillium expansum using dry conidia applied to pear fruit in a settling tower. Five concentrations of conidia were applied to pear fruit, fruit were stored at $-1^{\circ} \mathrm{C}$ for 8 months, and stem end decay was evaluated. In addition, conidia were washed from the surface of inoculated fruit, and DNA was extracted and quantified with real-time polymerase chain reaction (PCR). The linear regression relationships between percent stem end gray mold and $B$. cinerea conidia per liter of air or per square centimeter of fruit surface were significant $(P=0.01)$. At the highest inoculum dose introduced into the settling tower, conidia per liter of air, conidia per square centimeter, and percent stem end gray mold at 8 months after inoculation were 12, 31, and 39, respectively for 2000 and 6,33 , and 67 , respectively for 2001. Similarly, the linear regression relationships between percent stem end blue mold and $P$. expansum conidia per liter of air or per square centimeter of fruit surface were significant $(P=0.01$ and 0.05 , respectively). At the highest inoculum dose introduced into the settling tower, conidia per square centimeter and percent stem end blue mold at 8 months after inoculation were 39 and 26, respectively for 2000 and 66 and 23, respectively for 2003. Real-time PCR provided a rapid, quantitative measure of B. cinerea and P. expansum DNA on pear fruit surfaces. Because of possible year-to-year shifts in susceptibility of fruit to decay, disease incidence:inoculum dose relationships may be of most value compared within years rather than across years. This would facilitate comparison of decay risk among orchards in order to determine which fruit is most suitable for long-term storage.
\end{abstract}

The two most important postharvest storage decays of apple and pear fruit are gray mold and blue mold caused by $\mathrm{Bo}$ trytis cinerea Pers. and Penicillium expansum Link, respectively $(10,14,16)$. Conidia of these fungi can become airborne and contaminate the surfaces of fruit and bins used for storage of fruit during harvest $(11,16,23)$. Infection of fruit occurs when spores enter wounds or infect through the abscission zone of the pedicel (stem) $(3,14,20,21,24,25)$. This may occur during harvest or later, as fruit float through contaminated dump tank or flume water in the packinghouse $(9,22)$. Stem tissue of d'Anjou pear is susceptible to infection at harvest and remains sus-

Corresponding author: R. A. Spotts

E-mail: robert.spotts@oregonstate.edu

Use of trade names in this article does not imply endorsement by Oregon State University of the products named or criticism of similar products not mentioned.

Accepted for publication 31 October 2007.

doi:10.1094/PDIS-92-3-0451

(C) 2008 The American Phytopathological Society
(4), and inoculum dispersal dynamics of brown rot of stone fruit (12).

The objective of this research was to determine quantitative relationships between incidence of stem end gray mold and stem end blue mold of pear fruit and inoculum dose using dry conidia applied in a settling tower. In addition, inoculum dose of $B$. cinerea and $P$. expansum applied to fruit was quantified with qPCR.

\section{MATERIALS AND METHODS}

Fruit. d'Anjou pear fruit were harvested at commercial maturity with flesh firmness of 67 newtons at the Mid-Columbia Agricultural Research and Extension Center (MCAREC), Hood River, OR. Fruit were stored in air at $-1.1^{\circ} \mathrm{C}$ in cardboard fruit boxes lined with perforated polyethylene bags and used within 3 months of harvest. Fruit surfaces were disinfested with $100 \mu \mathrm{g}$ of sodium hypochlorite per milliliter of water for 2 min and rinsed with tap water before inoculation.

Inoculum. $B$. cinerea isolate 62 , originally obtained from an infected d'Anjou pear fruit in 1982 but inoculated and reisolated annually from pear fruit, was cultured on potato dextrose agar acidified (Difco Laboratories, Detroit) with $1.5 \mathrm{ml}$ of $85 \%$ lactic acid per liter (APDA) to prevent bacterial contamination. Conidia were harvested dry from 14-day-old cultures with a cyclone surface sampler (Burkard Manufacturing Co. Ltd., Rickmansworth, Hertfordshire, England). Dry conidia were diluted 1:99 with talc (T2015; Sigma-Aldrich, St. Louis) that had been sterilized at $140^{\circ} \mathrm{C}$ for $4 \mathrm{~h}$. The conidia and talc were mixed together for $5 \mathrm{~h}$ at $15^{\circ} \mathrm{C}$ in a twin shell blender (model SB-8; Patterson-Kelly Co., E. Stroudsburg, PA). The conidia/talc mix was stored at $3{ }^{\circ} \mathrm{C}$ and used as inoculum over a 6-week period. Germination of conidia in the mix was determined prior to each experiment by mixing with sterile distilled water, placing drops on APDA, and observing germination of 100 conidia microscopically at $\times 250$ after $24 \mathrm{~h}$ at $20^{\circ} \mathrm{C}$.

$P$. expansum isolate 46 , originally obtained from an infected d'Anjou pear fruit in 1980 but inoculated and reisolated annually from pear fruit, was cultured on APDA and spores harvested from 7-dayold cultures as described above. Conidia 
were mixed 1:99 with talc and stored until use as described above.

Inoculation. Pear fruit were inoculated in an aluminum tower $2.06 \mathrm{~m}$ high by $0.68 \mathrm{~m}$ wide by $0.68 \mathrm{~m}$ deep. Prior to each experiment, the room floor was sprayed with $5.25 \mathrm{~g}$ of sodium hypochlorite per liter of water, and the room air was sprayed with Lysol $(0.1 \%$ alkyl dimethyl benzyl ammonium saccharinate plus $79 \%$ ethanol; L \& F Products, Montvale, NJ). The inside of the tower was sterilized with $95 \%$ ethanol. After each inoculation, air was exhausted from the tower for $2 \mathrm{~min}$ with a blower vented outside the building, resulting in 8.8 complete air changes $\left(8.38 \mathrm{~m}^{3}\right)$.

Fruit with stems pointing straight up were placed in two cardboard trays, 22 fruit per tray, in the bottom of the tower. Inoculation temperature was $15 \pm 3^{\circ} \mathrm{C}$. Conidia/talc mixtures ranging from 1.0 to $5.0 \mathrm{mg}$ were used to obtain inoculum ranging from 0.01 to $0.05 \mathrm{mg}$ of conidia. Each mixture was weighed, transferred to a sterile glass tube of 6-mm internal diameter, and forcefully blown into the top center of the tower with 12 squeezes of an aspirator bulb. Spores were allowed to settle for $20 \mathrm{~min}$, and then fruit were re-
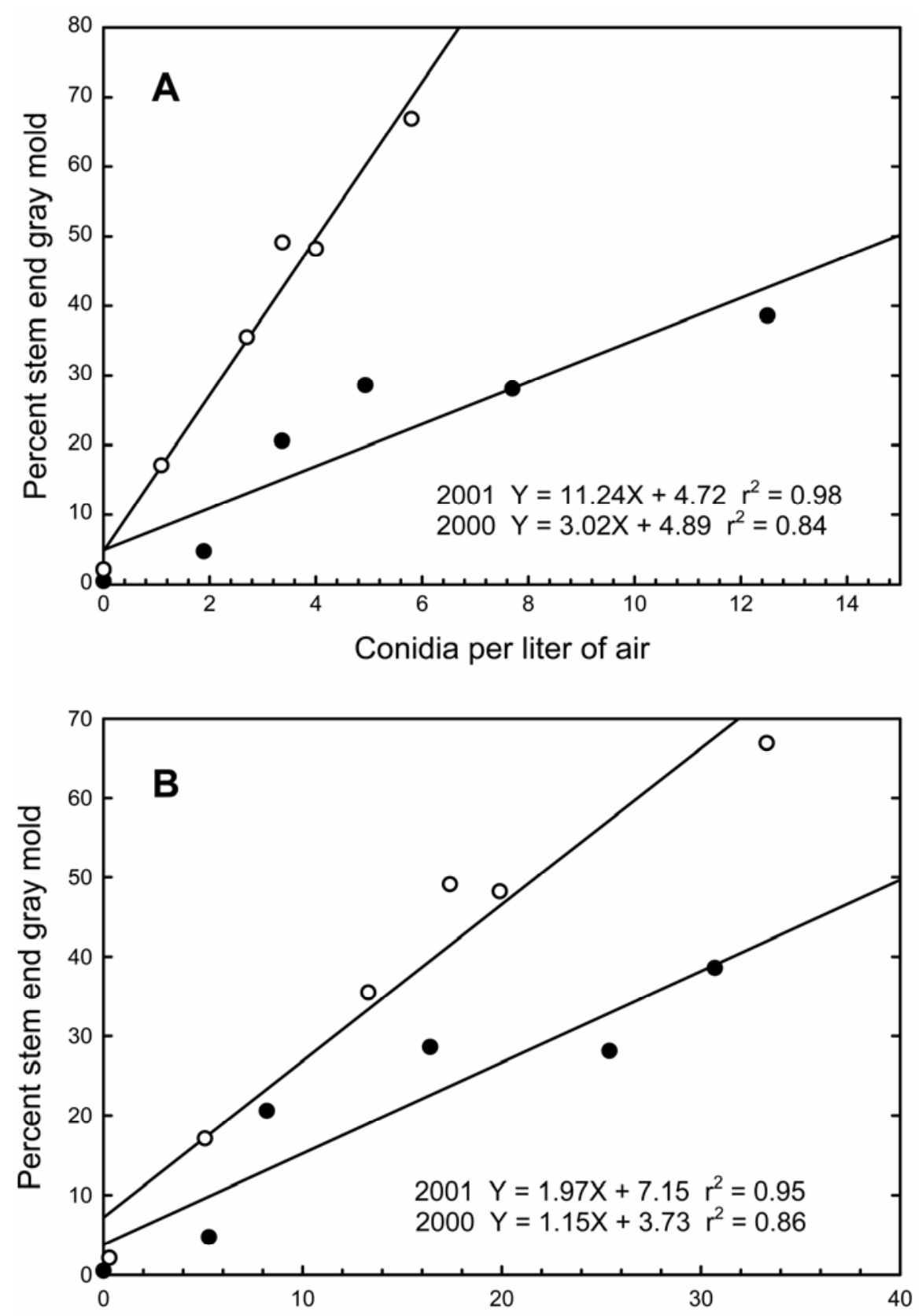

Number of conidia per $\mathrm{cm}^{2}$ of surface

Fig. 1. Relationship between incidence of stem end gray mold of d'Anjou pear fruit and inoculum dose of Botrytis cinerea expressed as $\mathbf{A}$, number of conidia per liter of air and $\mathbf{B}$, conidia per square centimeter of surface. Inoculations were done in 2000 (closed circles) and 2001 (open circles) and decay evaluated after 3,6 , and 8 months of incubation at $-1^{\circ} \mathrm{C}$.

moved. Control fruit were placed in the tower for $20 \mathrm{~min}$ but no inoculum was introduced. Each inoculum concentration of $B$. cinerea was replicated five times in 2000 and 2001. Each concentration of $P$. expansum was replicated five times in 2000 and four times in 2003. All replications each year were done within 6 weeks. Fruit were placed in a cardboard fruit box lined with a perforated polyethylene bag. After 3, 6, and 8 months of incubation at $-1^{\circ} \mathrm{C}$, infection in the flesh of the fruit that originated at the stem end was determined visually. Decayed fruit were removed after each evaluation to prevent secondary spread. Numbers of decayed fruit from all evaluations were totaled and incidence of stem end decay was calculated.

Density of conidia of $B$. cinerea settling onto surfaces was determined by placing three 2.54-by-7.62-cm glass microscope slides coated with a thin layer of silicone grease at different locations on the trays. At the end of each inoculation, slides were removed and stained with cotton blue in lactophenol, and conidia in 40 microscope fields counted at $\times 250$. Density of spores of $P$. expansum on the surface was determined by placing three 100-by-15-mm petri dishes containing APDA on the trays. After exposure, plates were incubated at $22^{\circ} \mathrm{C}$ for $24 \mathrm{~h}$ and colonies were counted with the aid of a stereomicroscope at $\times 15$.

Concentration of conidia of $B$. cinerea and $P$. expansum in the air inside the tower was determined by sampling with a portable air sampler for agar plates (Burkard Manufacturing Co. Ltd.). The manufacturer rates impaction efficiency of this sampler at $100 \%$ for 5 - $\mu \mathrm{m}$ particles at the 20-liters/min sampling rate used herein. Air was sampled through a port on the side of the tower $15 \mathrm{~cm}$ above the bottom. Air was sampled onto the same APDA plate for $15 \mathrm{~s}$ at $5,10,15$, and 19 min after inoculation for a total sample volume of 20 liters. Plates were incubated at $22^{\circ} \mathrm{C}$ and colonies counted after 1 to 2 days.

Fruit washing and DNA isolation. Inoculated fruit were weighed and washed on a rotary shaker followed by sonication, and surface area was calculated as previously described (11). Spores in wash water were concentrated by successive centrifugation starting with $200 \mathrm{ml}$ of original wash water that was concentrated to $10 \mathrm{ml}$ and finally to $100 \mu \mathrm{l}$ at $12,000 \mathrm{rpm}$ for 10 min, 7,000 rpm for $10 \mathrm{~min}$, and 6,000 rpm for $1 \mathrm{~min}$, respectively. Genomic DNA was isolated using the UltraClean Soil DNA Kit (MoBio, Solana Beach, CA) following the manufacturer's instructions.

Oligonucleotide primer selection. The software package OLIGO 6.3 (MBI, Cascade, $\mathrm{CO}$ ) was used to design primers used in this study. Both PCR primers for $P$. expansum (Pex-bt-37f 5' TTG AGC CTT ACA ACG CCA CT 3' and Pex-bt-384r 5' TTG ACC TGG CGG TAA GAG GA 3') were selected from $\beta$-tubulin sequence 
alignments from another study (18). These Penicillium primers produced a PCR product of approximately $350 \mathrm{bp}$. Design of the Botrytis primer Bcin-366r (5'TGA GTC AAC TCT GGA ACG $3^{\prime}$ ) used $\beta$-tubulin $B$. cinerea sequences available in GenBank (U27198, X73133, and Z69263). The primer was paired with a more generic primer BT-2M-Up (5'CAA CTG GGC TAA GGG TCA TT 3') (5) to produce a 568-bp product. Primer sequences were screened by performing Blast searches for homology with fungal sequences in the GenBank database. Additionally, to determine if qPCR melting curve analysis could be used as a discriminating tool to differentiate species sharing highly similar sequence homologies, melting temperatures were calculated for any potential amplicon sequences found in GenBank.

Real-time PCR assay. Samples $(20 \mu \mathrm{l}$ each) were prepared by mixing $1 \mu \mathrm{l}$ of DNA solution with $6.8 \mu \mathrm{l}$ of sterile distilled water, $10 \mu \mathrm{l}$ of DyNAmo HS SYBR Green qPCR Kit (Finnzymes, Espoo, Finland), $1 \mu$ of each primer mentioned previously (final concentration 200nM), and $0.2 \mu \mathrm{l}$ of UltraTherm DNA polymerase (Boca Scientific, Boca Raton, FL). Realtime PCR reactions were run in triplicate on a DNA Engine Opticon 2 System (MJ Research, Inc., Walttham, MA). After a 10min denaturation step at $95^{\circ} \mathrm{C}$, samples were run for 40 cycles of $10 \mathrm{~s}$ at $94^{\circ} \mathrm{C}, 20 \mathrm{~s}$ at $55.8^{\circ} \mathrm{C}$ for $B$. cinerea and $20 \mathrm{~s}$ at $58^{\circ} \mathrm{C}$ for $P$. expansum, and $15 \mathrm{~s}$ at $72^{\circ} \mathrm{C}$ for both fungi. A final extension was done at $72^{\circ} \mathrm{C}$ for $10 \mathrm{~min}$. Melting curves were measured starting at $75^{\circ} \mathrm{C}$ and increasing by $0.2^{\circ} \mathrm{C}$ every $1 \mathrm{~s}$ until $90^{\circ} \mathrm{C}$ was reached. Positive controls (standards) consisted of DNA extracted from Bot62 and Pen46 and quantified using a spectrophotometer, reading transmittance at 260 and $280 \mathrm{~nm}$. Five serial 10-fold dilutions of these standards were run in triplicate in the same reaction as the samples. Three negative controls, consisting of $1 \mu \mathrm{l}$ of sterile distilled water added to the qPCR mix in place of the DNA solution, were included per run.

Statistics. The relationships between decay incidence and inoculum dose, expressed as both conidia per square centimeter of surface and conidia per liter of air, were plotted and subjected to linear regression analysis. The analysis of variance procedure (Minitab, State College, PA) was used to determine significance among regressions. Linear regression also was used to describe the relationships between DNA on the fruit surface and the quantity of conidia applied as well as conidia per square centimeter of surface (trial 2 only).

\section{RESULTS}

Germination of conidia of $B$. cinerea was between 93 and $100 \%$ for all experiments. The linear regression relationships between percent stem end gray mold and
B. cinerea conidia per liter of air or per square centimeter of surface were significant at $P=0.01$, except for the regression in year 2000 of decay versus conidia per liter of air, which was significant at $P=$ 0.05 (Fig. 1A and B). At the highest inoculum dose introduced into the settling tower, conidia per liter of air, conidia per square centimeter, and percent stem end gray mold at 8 months after inoculation were 12,31 , and 39 , respectively, for 2000 and 6, 33, and 67, respectively, for 2001. For both decay regressed on conidia per liter and per square centimeter, the slopes of the regression lines were significantly different for year 2000 versus 2001 .
Germination of conidia of $P$. expansum in the talc powder was 96 to $100 \%$ during the 4 weeks it took to complete the inoculation experiments. The regression of stem end blue mold on conidia per liter of air was significant at $P=0.01$ (Fig. $2 \mathrm{~A}$ ). There was no difference in slope or $\mathrm{Y}$ intercept of regression lines of stem end blue mold versus conidia per square centimeter for 2000 and 2003, and data for the 2 years were combined. The resulting regression was significant at $P=0.05$ (Fig. 2B). At the highest inoculum dose introduced into the settling tower, conidia per square centimeter and percent stem end blue mold at 8 months after inoculation were 39 and 26 ,
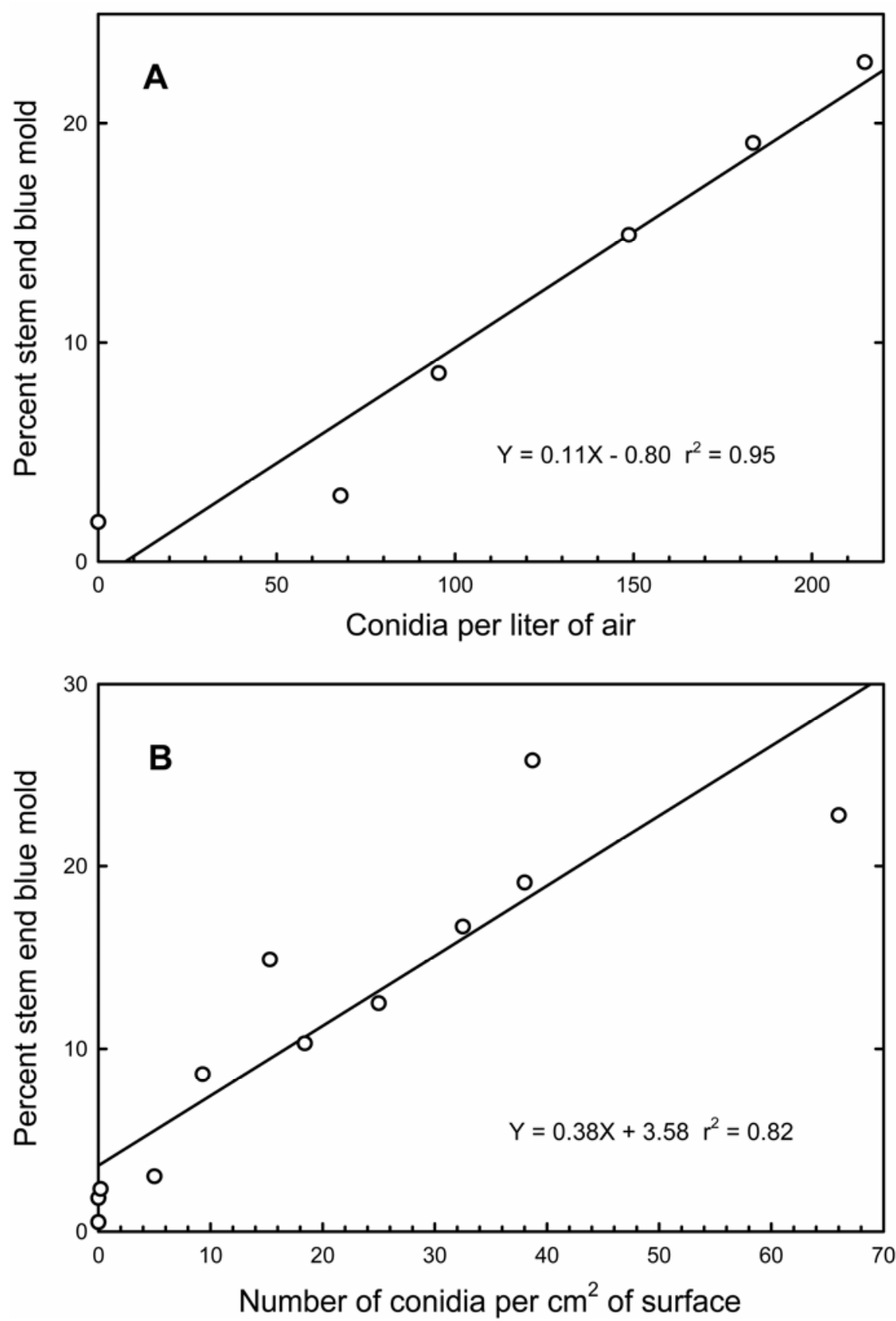

Fig. 2. Relationship between incidence of stem end blue mold of d'Anjou pear fruit and inoculum dose of Penicillium expansum expressed as A, number of conidia per liter of air (2003 only) and $\mathbf{B}$, conidia per square centimeter of surface (data from 2000 and 2003 combined). Decay was evaluated after 3, 6, and 8 months of incubation at $-1^{\circ} \mathrm{C}$. 
Table 1. Quantification of fungal DNA on the surface of d'Anjou pear fruit inoculated with dry conidia of Botrytis cinerea and Penicillium expansum using a real-time polymerase chain reaction assay ${ }^{\mathrm{a}}$

\begin{tabular}{|c|c|c|c|c|c|c|}
\hline \multirow[b]{3}{*}{ Conidia applied $(\mathrm{mg})^{\mathrm{b}}$} & \multicolumn{3}{|c|}{ B. cinerea } & \multicolumn{3}{|c|}{ P. expansum } \\
\hline & \multirow{2}{*}{$\begin{array}{c}\text { Trial } 1 \\
\text { DNA }\left(\mathrm{pg} / \mathrm{cm}^{2}\right)^{\mathrm{c}}\end{array}$} & \multicolumn{2}{|c|}{ Trial 2} & \multirow{2}{*}{$\begin{array}{c}\text { Trial 1 } \\
\text { DNA }\left(\mathrm{pg} / \mathrm{cm}^{2}\right)^{\mathrm{f}}\end{array}$} & \multicolumn{2}{|c|}{ Trial 2} \\
\hline & & DNA $\left(\mathrm{pg} / \mathrm{cm}^{2}\right)^{\mathrm{d}}$ & Conidia/cm ${ }^{2 e}$ & & DNA $\left(\mathrm{pg} / \mathrm{cm}^{2}\right)^{\mathrm{g}}$ & Conidia/ $/ \mathrm{cm}^{2 \mathrm{~h}}$ \\
\hline 0.00 & 0.10 & 0.09 & 0.7 & 0.08 & 0.07 & 0.0 \\
\hline 0.01 & 0.47 & 0.72 & 3.7 & 0.25 & 0.07 & 5.2 \\
\hline 0.02 & 0.64 & 1.40 & 6.1 & 0.24 & 0.08 & 13.2 \\
\hline 0.03 & 1.17 & 1.57 & 12.3 & 0.35 & 0.17 & 23.8 \\
\hline 0.04 & 1.35 & 1.74 & 16.4 & 0.36 & 0.24 & 26.3 \\
\hline 0.05 & 2.44 & 2.94 & 28.0 & 0.39 & 0.28 & 32.9 \\
\hline
\end{tabular}

a Mean of three replications of five fruit per replicate per trial.

${ }^{\mathrm{b}}$ Conidia mixed 1:99 in talc and applied to fruit in settling tower.

${ }^{c}$ Regression equation is $y=42.5 x-0.034$ where $y=$ picograms of DNA $/ \mathrm{cm}^{2}$ and $x=$ milligrams of conidia applied, $P=0.003, R^{2}=0.916$.

${ }^{\mathrm{d}}$ Regression equation is $y=50.0 x+0.162$ where $y=$ picograms of DNA $/ \mathrm{cm}^{2}$ and $x=$ milligrams of conidia applied, $P=0.002, R^{2}=0.930$.

e Regression equation is $y=0.093 x+0.371$ where $y=$ picograms of DNA $/ \mathrm{cm}^{2}$ and $x=\operatorname{conidia} / \mathrm{cm}^{2}, P=0.002, R^{2}=0.923$.

${ }^{\mathrm{f}}$ Regression equation is $y=5.78 x+0.135$ where $y=$ picograms of DNA $/ \mathrm{cm}^{2}$ and $x=$ milligrams of conidia applied, $P=0.007, R^{2}=0.869$.

g Regression equation is $y=4.55 x+0.039$ where $y=$ picograms of DNA $/ \mathrm{cm}^{2}$ and $x=$ milligrams of conidia applied, $P=0.004, R^{2}=0.893$.

${ }^{\mathrm{h}}$ Regression equation is $y=0.007 x+0.037$ where $y=$ picograms of DNA $/ \mathrm{cm}^{2}$ and $x=\operatorname{conidia} / \mathrm{cm}^{2}, P=0.005, R^{2}=0.882$.

respectively for 2000 and 66 and 23, respectively for 2003. Conidia per liter of air was 215 in 2003 but was not determined in 2000 .

Initial Blast searches of the GenBank database with Bcin-366r/ BT-2M-Up sequences showed the primer pair to be specific for B. cinerea; however, later conformational searches revealed potential crossreactions with several other species $(B$. fabae, Monilinia fructicola, M. laxa, and Sclerotinia sclerotiorum). Blast search using Pex-bt-37f /Pex-bt-384r sequences indicated the primer pair to be specific for P. expansum.

The qPCR melting curve analysis for $P$. expansum control and sample DNA (using Pex-bt-37f/Pex-bt-384r) produced an amplicon with a melting point (Tm) of $86.0^{\circ} \mathrm{C}$, and amplification products from control and sample DNA of $B$. cinerea (using Bcin-366r/ BT-2M-Up) gave a Tm value of $82.8^{\circ} \mathrm{C}$. Melting curve analysis was conducted using $0.2^{\circ} \mathrm{C}$ incremental steps. Calculated $\mathrm{Tm}$ values for closely related $\beta$-tubulin sequences from GenBank ( $P$. commune, $P$. solitum, and $P$. aurantiogriseum) differed from $P$. expansum by 0.4 to $1.1^{\circ} \mathrm{C}$ and sequences of $M$. fructicola, M. laxa, and S. sclerotiorum from $B$. cinerea by 0.3 to $0.5^{\circ} \mathrm{C}$.

Quantities of DNA of $B$. cinerea and $P$. expansum on the surfaces of inoculated pear fruit were determined with qPCR (Table 1). The relationships between fungal DNA and inoculum dose were highly significant $(P \leq 0.01)$, as were relationships between fungal DNA and conidial surface density. Quantities of DNA of $B$. cinerea on the fruit surfaces exceeded those of $P$. expansum at all inoculum concentrations (Table 1).

\section{DISCUSSION}

In a previous study, the relationships between disease incidence at puncturewound sites on pear fruit and inoculum dose of dry airborne conidia of $B$. cinerea and $P$. expansum were determined (24).
The relationships described herein are extensions of that study to the infection court at the abscission zone of the stem. Interestingly, similar concentrations of dry inoculum caused similar incidences of infection in both studies. For example, 200 conidia/liter of air of $P$. expansum caused infection at $29 \%$ of punctures (24) and at $21 \%$ of stems herein.

Pear decay originating at stem ends is of commercial significance (10), and a better understanding of the disease incidence:inoculum dose (DI:ID) relationship is an important component of an integrated control strategy. Integrated decay control systems involving nutrition, harvest maturity, biocontrol, fungicides, and sanitation have been developed $(27,28,30)$. Several of these components, particularly removal of fallen fruit, fungicides, and sanitation, lower the inoculum dose in the orchard. The density of fungal propagules on the fruit surface at harvest appears to be a good predictor of the incidence of postharvest decay (9). Furthermore, biocontrol agents are more effective in low-inoculum situations $(7,15)$.

The fungicide ziram often is applied 2 to 3 weeks prior to harvest to pome fruit trees in the Pacific Northwest (30) and reduces total decay by about $25 \%$. Because we did not include fruit treated with ziram in our study, the effect of ziram or other preharvest fungicides on the DI:ID relationships requires further research. A second factor that requires additional study is host susceptibility. We found that the relationship between stem end gray mold and inoculum dose was significantly different for 2000 versus 2001. Year-to-year shifts in susceptibility of fruit to decay may be related to seasonal temperature and moisture fluctuations, resulting in altered levels of polygalacturonase inhibitors, phenolics, and phytoalexins as well as physical changes such as cuticle thickness $(2,13,19,20,29)$. Thus, the DI:ID relationship may differ for each cropping season and be of most value within years rather than across years. This would facilitate comparison of decay risk among orchards in order to determine which fruit is most suitable for long-term storage.

Research is in progress to predict the amount of gray mold and blue mold decay developing in long-term cold storage based on populations of $B$. cinerea and $P$. expansum on the fruit surface as determined by standard dilution plating and DNA quantification with qPCR. We demonstrated herein that inoculum on the fruit surface can be rapidly and accurately determined with qPCR and that picograms of DNA per square centimeter of fruit surface is a good measure of the surface density of conidia. Previously, qPCR has been used to quantify airborne spores of $M$. fructicola (12) and Fusarium circinatum (17). Extensive orchard sampling will be necessary to obtain a large data base of naturally occurring DNA concentrations of $B$. cinerea and $P$. expansum on pear fruit surfaces at harvest before thresholds can be determined for use in a decay risk prediction model.

\section{ACKNOWLEDGMENTS}

We thank the Fresh and Processed Pear Subcommittee for partial funding of the research.

\section{LITERATURE CITED}

1. Atallah, Z. K., and Stevenson, W. R. 2006. A methodology to detect and quantify five pathogens causing potato tuber decay using real-time quantitative polymerase chain reaction. Phytopathology 96:1037-1045.

2. Boonyakiat, D., Spotts, R. A., and Richardson, D. G. 1986. Effects of chlorogenic acid and arbutin on growth and spore germination of decay fungi. HortScience 21:309-310.

3. Chen, P. M., Spotts, R. A., and Mellenthin, W. M 1981. Stem-end decay and quality of low oxygen stored d'Anjou pears. J. Am. Soc. Hortic. Sci. 106:695-698.

4. Chilvers, M. L., duToit, L. J., Akamatsu, H., and Peever, T. L. 2007. A real-time quantitative PCR seed assay for Botrytis spp. that cause neck rot of onion. Plant Dis. 91:599-608.

5. de Jong, S. N., Levesque, C. A., Verkley, G. J. M., Abeln, E. C. A., Rahe, J. E., and Braun, P. G.. 2001. Phylogenetic relationships among Neofabraea species causing tree cankers and bull's-eye rot of apple based on DNA sequencing of ITS nuclear rDNA, mitochondrial 
rDNA, and the b-tubulin gene. Mycol. Res. 105:658-669.

6. Haugland, R. A., Varma, M., Wymer, L. J., and Vesper, S. J. 2004. Quantitative PCR analysis of selected Aspergillus, Penicillium, and Paecilomyces species. Syst. Appl. Microbiol. 27:198-210.

7. Jijakli, M. H., Lepoivre, P., Tossut, P., and Thonard, P. 1993. Biological control of Botrytis cinerea and Penicillium on post-harvest apples by two antagonistic yeasts. Meded. Fac. Landbouwwet. Rijksuniv. Gent. 58:1349-1358.

8. Lennox, C. L., and Spotts, R. A. 1997. Botrytis gray mold as a postharvest pathogen in d'Anjou pear. Pages 93-95 in: Proc. 13th Annu. Wash. Tree Fruit Postharvest Conf. E. Kupferman, ed. Washington State Horticultural Association, Wenatchee.

9. Lennox, C. L., and Spotts, R. A. 2004. Timing of preharvest infection of pear fruit by Botrytis cinerea and the relationship to postharvest decay. Plant Dis. 88:468-473.

10. Lennox, C. L., Spotts, R. A., and Booyse, M. 2004. Incidence of postharvest decay of 'd'Anjou' pear and control with a thiabendazole drench. Plant Dis. 88:474-478.

11. Lennox, C. L., Spotts, R. A., and Cervantes, L. A. 2003. Populations of Botrytis cinerea and Penicillium spp. on pear fruit and in orchards and packinghouses, and their relationship to postharvest decay. Plant Dis. 87:639-644.

12. Luo, Y., Ma, Z., Reyes, H. C., Morgan, D., and Michailides, T. J. 2007. Quantification of airborne spores of Monilinia fructicola in stone fruit orchards of California using real-time PCR. Eur. J. Plant Pathol. 118:145-154.

13. Michailides, T. J. 1991. Russeting and russet scab of prune, and environmentally induced fruit disorder: symptomatology, induction, and control. Plant Dis. 75:1114-1123.
14. Pierson, C. F., Ceponis, M. J., and McColloch, L. P. 1971. Market diseases of apples, pears, and quinces. Agric. Handb. 376, U. S. Dep. Agric. Washington, DC

15. Saligkarias, I. D., Gravanis, F. T., and Epton, H. A. S. 2002. Biological control of Botrytis cinerea on tomato plants by use of the epiphytic yeasts Candida guilliermondii strains 101 and US 7 and Candida oleophila strain I-182: I. In vivo studies. Biol. Control 25:143-150.

16. Sanderson, P. G., and Spotts, R. A.. 1995. Postharvest decay of winter pear and apple fruit caused by species of Penicillium. Phytopathology 85:103-110.

17. Schweigkofler, W., O'Donnell, K., and Garbelotto, M. 2004. Detection and quantification of airborne conidia of Fusarium circinatum, the causal agent of pine pitch canker, from two California sites by using a real-time PCR approach combined with a simple spore trapping method. Appl. Environ. Microbiol. 70:3512-3520.

18. Sholberg, P. L., Harlton, C., Haag, P., L'evesque, C. A., O'Gorman, D., and Seifert, K. 2004. Benzimidazole and diphenylamine sensitivity and identity of Penicillium spp. that cause postharvest blue mold of apples using $\beta$ tubulin gene sequences. Postharvest Biol. Technol. 36:41-49.

19. Skoss, J. D. 1955. Structure and composition of plant cuticle in relation to environmental factors and permeability. Bot. Gaz. Chicago 117:55-72.

20. Sommer, N. L. 1992. Principles of disease suppression by handling practices. Pages 109-116 in: Postharvest Technology of Horticultural Crops, 2nd ed. A. A. Kader, ed. University of California, Oakland.

21. Spotts, R. A. 1986. Relationships between inoculum concentration of three decay fungi and pear fruit decay. Plant Dis. 70:386-389.

22. Spotts, R. A., and Cervantes, L. A. 1986. Popula- tions, pathogenicity, and benomyl resistance of Botrytis spp., Penicillium spp., and Mucor piri formis in packinghouses. Plant Dis. 70:106-108.

23. Spotts, R. A., and Cervantes, L. A. 1994. Contamination of harvest bins with pear decay fungi and evaluation of disinfestants on plastic and wood bin material. Acta Hortic. 367:419-425

24. Spotts, R. A., and Cervantes, L. A. 2001. Disease incidence-inoculum dose relationships for Botry tis cinerea and Penicillium expansum and decay of pear fruit using dry, airborne conidia. Plant Dis. 85:755-759.

25. Spotts, R. A., Sanderson, P. G., Lennox, C. L., Sugar, D., and Cervantes, L. A. 1998. Wounding, wound healing and staining of mature pear fruit. Postharvest Biol. Technol. 13:27-36.

26. Suarez, M. B., Walsh, K., Boonham, N., O’Neill, T. O., Pearson, S., and Barker, I. 2005. Development of real-time PCR (TaqMan) assays for the detection and quantification of Botrytis cinerea in planta. Plant Physiol. Biochem. 43:890-899.

27. Sugar, D., Righetti, T. L., Sanchez, E. E., and Khemira, H. 1992. Management of nitrogen and calcium in pear trees for enhancement of fruit resistance to postharvest decay. HortTechnology 2:382-387.

28. Sugar, D., Roberts, R. G., Hilton, R. J., Rhigetti, T. L., and Sanchez, E. E. 1994. Integration of cultural methods with yeast treatment for control of postharvest fruit decay in pear. Plant Dis. 78:791795.

29. Whitecross, M. I., and Armstrong, D. J. U. 1972. Environmental effects on epicuticular waxes of Brassica napus L. Aust. J. Bot. 20:87-95

30. Willett, M., Kupferman, E., Roberts, R., Spotts, R., Sugar, D., Apel, G., and Ewart, H W. 1992. Integrated management of the postharvest diseases and disorders of apples, pears, and cherries. Tree Fruit Postharvest J. 3:3-16. 